\title{
Indonesia's fight for a law against sexual violence needs to involve a discussion of Islamic values
}

Edition 8, 2021

Dr Dina Afrianty

DOI: 10.37839/MAR2652-550X8.23

This year, the House of Representatives of Indonesia (DPR) has returned for the second time in five years to the subject of law reform in the effort to eliminate sexual violence. This follows many years of lobbying by women's rights advocates seeking wide ranging reform to end sexual violence and violence against women as part of their efforts to promote women's rights and gender equality. Right from the beginning, such efforts have faced persistent opposition from conservatives and from parliamentary representatives both from Islamic and secular political parties.

The public policy debate surrounding the deliberation of the elimination of sexual violence bill in the past five years has been framed in terms of religious doctrine and state ideology. The first principle of Pancasila, which could be considered state ideology enshrined in the Constitution, is 'Belief in One God.' This is widely interpreted to mean that any public policy, in particular those pertaining to morality, must be based on religion-in this case Islam. Certain conceptions of human rights, and women's rights are being cast as merely a Western construct which contradicts Islamic norms and therefore not worthy of respect and which must not define public policy making. 


\section{Sexual violence against women in Indonesia}

Indonesia's National Commission on Violence Against Women, Komnas Perempuan, publishes annual reports on violence against women which reveal an increase in reported occurrences of community, state, and family violence. According to its 2019 Annual Report, incidents increased from 348,446 to 406,178 between 2017 and 2018. The largest source of data is that provided by Religious Courts, and Komnas Perempuan has used this to identify various forms of violence cited as grounds for divorce considered by the courts.

What these annual reports demonstrate is that Indonesian women are subject to widespread sexual and gender-based violence, including in the home, the workplace, and in many other public settings. The ongoing struggle of women to be respected and treated equally in public and private domains is also reflected in an upsurge in the reporting of online-based violence in recent years, including sexting, cyber bullying, and 'revenge-porn'. A report by The Coalition of Civil Society (Jaringan Masyarakat Sipil) and Komnas Perempuan demonstrated the physical and psychological impacts of sexual violence on victims and how it seriously affects their quality of life. In addition, the report also suggests violence not only affects the individual, it also negatively affects their families and the community.

Fundamentally, these are among the concerns that have been raised by women's rights advocates for a long time, including a campaign against child marriage. I argue that the perpetual violence directed against women is the result of a culture of impunity for perpetrators, and there is a need for a misogynist culture marked by male privilege to be addressed through a comprehensive legal framework.

\section{Path to reform}

After years of study and research, Komnas Perempuan and civil society organisations produced a detailed draft law which was submitted to parliament in 2017. Reflecting 
its status as a priority bill this was called Rancangan Undang-Undang Penghapusan Kekerasan Seksual (RUU PKS), the Elimination of Sexual Violence Bill (ESVB).

ESVB sought to outlaw nine forms of conduct including sexual harassment, sexual exploitation, forced contraception, forced abortion, rape, forced marriage, forced prostitution, sexual slavery, and sexual abuse. The bill addressed not only criminal procedures, but also covered aspects of prevention, case management, the protection of the rights of the victims and their families, and rehabilitation. Importantly, in its prevention aspect, it emphasised the need for sex education and education relating to discrimination against women within the law enforcement community, as well as among the wider public. This approach was driven by a belief that eliminating sexual violence requires a comprehensive approach including educating society about sexuality, respect for women's rights and the promotion of gender equality.

The DPR held public hearings to respond to the bill throughout the 2018-2019 legislative term. Simultaneously, public debate exploded, particularly on social media. Both advocates and opponents of the bill launched public campaigns to influence public discourse, with each group identifying their viewpoint using hashtags such as \#SahkanRUUPKS (accept the bill) and \#TolakRUUPKS (reject the law).

\section{Public responses to the bill}

At the core of the public debate was the resistance from elements of the Muslim community (including members of the DPR) and conservative Islamic Political Parties, in particular the Prosperous Justice Party (Partai Kesejahteraan Sosial, PKS). Essentially, opponents were strongly motivated by the opinion that the bill was driven by a Western, feminist agenda and that the bill contradicted Indonesia's religious and cultural values. The conservative Islamic women's group AILA, or Family Love Alliance, was a leading conservative voice throughout the debate, firmly 
rejecting the draft's rhetoric of women's rights, gender equality, and individual freedom. The campaign run by conservative groups have misled the public claiming, among other things, that the legal framework will legalise consensual relations involving unmarried couples, same sex relations, abortion, and prostitution.

The criticism of the bill as being 'Western' arose because the bill categorised certain conduct as criminal where a woman did not consent, defined as arising in circumstances where it was not possible due to unequal power relations or gender relations. This approach was said to be heavily influenced by the concepts of 'individual liberty,' 'equality,' and 'rights.' This was seen as influenced by Western feminism and messages opposing the draft on social media platform have been phrased using the hashtags \#mybodymyreligion \#uninstallfeminism \#IndonesiaTanpaFeminis or \#IndonesiaWithoutFeminists.

Perhaps strangely, and unfairly, reliance on consent was criticised as encouraging loose moral behaviour, and the bill's opponents said that it implicitly supported any kind of sexual conduct involving consent. Opponents also indicated that they considered that religiously, or morally, inappropriate conduct such as homosexual sex, should be outlawed. Other than being somewhat irrelevant to the topic, this approach also meant that the significance of other important offences were ignored, thus undermining efforts to ban forced abortion, sexual slavery, and forced prostitution.

Conservative Muslims have been pressing for change to Indonesia's Criminal Code since 2016 to criminalise consensual sexual interactions outside marriage such as homosexuality. According to them, RUU PKS was Western propaganda designed to justify consensual sex outside marriage, including same-sex relationships, solely on the basis that each individual is granted the freedom to control their own body.

While it was originally thought that the measure would be voted into law in 2019, the bill was not passed by parliament before its dissolution ahead of the 2019 general election due to the level of opposition to the draft. 


\section{New draft-is there a new hope?}

Instead of the newly elected DPR continuing to discuss the bill, lawmakers chose to cancel it in July 2020. It was only in January 2021, following public protests, that the DPR agreed to reintegrate the ESVB as a priority bill in the 2020-2024 National Legislation Program (Prolegnas).

Thus, in February 2021, a fresh set of parliamentary hearings began, with public hearings featuring a coalition of civil society organisations, academics, and representatives of Islamic organisations. On 12 July 2021, a public hearing was conducted at which representatives from Islamic organisations, including AILA, and conservative religious personalities provided comment. The online meeting was also broadcast live on the House of Representatives' YouTube channel.

These groups reiterated their previous concerns, calling for the parliament to ensure that in this new round of policy deliberation, they ignore the previous draft because its formulation was, they argued, based on the work of Western feminists. Indonesia's response to sexual violence, according to them, must be framed within local values, in which Islam plays significant role. They specifically demanded that national law be founded on the teachings of Islam, and that Islamic principles be made the point of reference for developing public policy.

A day later, another DPR public hearing was held, this time with members of the academic community, women's rights groups, and a feminist Muslim organisation, the Female Ulama Congress or Kongres Ulama Perempuan Indonesia (KUPI). These groups reminded the DPR that failure to pass the bill meant that more women became victims of gendered violence in the space of two years (2019-2020). Therefore, they demanded the DPR learn from the evidence they provided which consisted of a rigorous study covering the empirical, theoretical, philosophical and sociological aspects on the need for a comprehensive legal framework to eliminate sexual violence. 
To everyone's surprise, the DPR responded by publishing a new bill on 30 August 2021. The bill is titled the 'Sexual Violence Crime Bill' (SVCB), Rancangan UndangUndang Tindak Pidana Kekerasan Seksual and contains some changes. First and foremost, it removes the word 'Penghapusan' (elimination) from the title. Accordingly, the draft omits the comprehensive framework previously provided for and instead focuses only on punishing criminal offences. Second, in contrast to the previous draft, the new bill only seeks to outlaw violent sexual crime, sexual harassment, forced contraception, sexual exploitation and forced sexual relations, leaving out, for example, forced marriage. Third, it also replaces the word 'Perkosaan' (rape) as a key act of sexual violence with 'forced sexual relations'.

Indonesia's Women's Legal Aid Network (LBH APIK) criticised the move as an attempt to disguise the violent act of rape. All in all, the new draft SVCB only has 43 Articles compared to 128 in the ESVB. Women's rights advocates have expressed their disappointment as the new draft reflects a concern with criminalising perpetrators, which is not enough to eliminate sexual violence.

The offences that are included in the new bill reflect a narrow and conservative approach to gender relations and forms of violence. The coalition of civil society movements against sexual violence (KOMPAKS, Koalisi Masyarakat Sipil Anti Kekerasan Seksual) criticised the new draft as focusing only on punishing sexual offenders without emphasising protection for victims. The removal of offences related to forced marriage, forced prostitution, forced abortion, and sexual slavery leaves victims vulnerable. Overall, the bill fails to properly address the full range of practices that advocates have pointed to as representing the different forms which violence can take, and to comprehensively respond to the gender discrimination underlying them.

\section{Muslim internal debates on gender}




\section{equality}

The Femala Ulama Congress, KUPI, a prominent organisation of feminist Muslim scholars, countered doctrinal criticisms made by their Muslim counterparts in AILA, conservative members of DPR, and Islamic organisations. According to KUPI, the concept of a new legal framework aimed at eradicating sexual violence is consistent with Islamic doctrine, which mandates that the state protect every human being from abuse and violent behaviour and promote justice. KUPI joined Komnas Perempuan and civil society organisations in the struggle to stop sexual violence in light of several studies demonstrating the catastrophic impact of sexual violence on victims, their families, and the community. KUPI proactively engages in public discourse, utilising Islamic ideas to contradict the narrative advanced by AILA and conservative organisations.

In 2020, KUPI published a pocket book and ran social media campaigns to educate the Muslim community on what Islam teaches about the need of protecting each individual's safety, and how Islam condemns violent acts. It emphasises the fact that in Islam, all relationships should be based on respect; and in connection to sexual relations, it emphasises that Islam teaches that everyone is equal. This equality means that it is important that social relations are based on voluntary commitment and lack of coercion. In addition, KUPI highlighted that it is also part of Islamic teaching that the state is obliged to protect every single citizen from fear.

\section{Where to from here?}

The impact of conservative Muslims in shaping Indonesian jurisprudence can be seen in the debate surrounding the deliberation of elimination of sexual violence against women. Once more, it is the rights and status of women that have been a priority target, rather than other pressing social and economic issues.

Women's rights are not a minority question: they are universal and ought to be self- 
evident to all. A woman's right to bodily autonomy and to choose how and when to engage in sexual intimacy is surely the most fundamental of all. Despite this, in 2021, Indonesian women are being told that their bodies do not belong to them, and that they must fulfil the obligations derived from certain conceptions of womanhood.

With democratic reform, Indonesia sought to throw off the constraints of statemandated doctrine, and authoritarianism. Yet decades later, we are still debating the nature and conditions for the experience of fundamental human rights. The ongoing public debate over the request for women to be protected against any form of violent behaviour is proving to be very difficult and challenging. Sadly, the unwillingness to acknowledge that men and women should have equal rights is justified through reference to the conservative interpretation of Islamic doctrine.

Time and again, Indonesians have been confronted by a conversation over the role of women where that role is defined and bound by cultural and traditional values. This was a theme under Soeharto's authoritarian rule, and now is one increasingly dominated by, and inspired by, Islamic values. This reminds us all that in an increasingly conservative society, gender equality and women's rights will continue to be a highly charged political and cultural issue.

It is too early to suggest what the outcomes will be. Certainly, there is considerable scope for further discussion within the Muslim community on truth in Islamic narratives, and for discourse about how to realise the rights of women and gender justice in a manner that does not undermine the status of, or discriminate against and disadvantage, women.

Image: Women on a bus in Indonesia. Credit: UN Women/Flickr. 